\title{
Effect of Thermal Compression Treatment on the Surface Hardness, Vertical Density Propile and Thickness Swelling of Eucalyptus Wood Boards by Hot-pressing*1
}

\author{
Oner Unsal $^{* 2}$, Zeki Candan*2, Umit Buyuksari*2, Suleyman Korkut*3, Yoon-Seong \\ Chang ${ }^{* 4}$, Hwanmyeong Yeo*4,5†
}

\begin{abstract}
Thermal treatment techniques are used for modifying wood and wood-based materials to improve dimensional stability and hygroscopicity. This study investigated the effects of press pressure and temperature on density, vertical density profile, thickness swelling and surface hardness of eucalyptus wood boards. The experimental wood boards were prepared from Turkish River Gum (Eucalyptus camaldulensis Dehn.). The surface hardness value increased with increasing press pressure in the treated groups. The application of a higher pressure at the same temperature level increased the amount of swelling of wood. It means that it is not needed for application of higher pressure to enhance the dimensional stability of wood. It is expected that it is possible to produce increased hardness, dimensional stability and durability by application of hot pressing treatment. This research showed that different press pressure and temperature values should be used to improve the performance properties of eucalyptus wood so that the end-use of the wood materials could be expanded.
\end{abstract}

Keywords : Thermal compressing, heat modification, dimensional stability, solid wood boards, spring-back phenomenon, density, Eucalyptus camaldulensis

\section{INTRODUCTION}

Turkish river red gum (Eucalyptus camaldulensis Dehn.) has been grown on plantations in the Tarsus region of Mersin, Turkey. This species has some advantageous such as fast growth and low price. However, it has several undesired properties such as low dimensional sta-

*1 Received on November 12, 2010; accepted on December 22, 2010

*2 Dept. of Forest Products Engineering, Faculty of Forestry, Istanbul University, Bahcekoy, Sariyer, 34473, Istanbul, Turkey

*3 Dept. of Forest Industrial Engineering, Faculty of Forestry, Duzce University, 81620 Duzce, Turkey

*4 Dept. of Forest Sciences, College of Agriculture and Life Sciences, Seoul National University, 599 Gwanak-ro, Gwanakgu, Seoul 151-921, Korea

*5 Research Institute for Agriculture and Life Sciences, College of Agriculture and Life Sciences, Seoul National University, 599 Gwanak-ro, Gwanak-gu, Seoul 151-921, Korea

† Corresponding author : Hwanmyeong Yeo (e-mail: hyeo@snu.ac.kr) 
bility and several drying problems limiting its use.

Heat treatment of wood and wood composites is known to improve and control dimensional stability, durability and discoloration (Burmester, 1973; Giebeler, 1983; Yeo et al., 2010). Various heat treatment procedures such as the Plato Process, Retification Process, Boise Perdure, OilHeat Treatment Process, and Thermowood Process are widely used in the forest products industry (Militz, 2002). Compression and temperature is generally used on wood products to improve their physical and mechanical properties. Thermally compressed wood is known as staypak (Seborg et al., 1945; Stamm, 1964), while compressed wood with phenol formaldehyde (PF) resin pretreatment is called compreg (Stamm, 1964; Stamm and Haris, 1953). Further studies were done by Tarkow and Seborg (1968) studying surface densification of wood. After the 1980s, compressed wood products with lower densities from cheaper wood species were produced, especially utilizing some of the fast growing trees in Asia (Norimoto, 1993, 1994; Wang, 2000).

Compression in wood is generally considered to be analogous to hot pressing wood composites, except that it takes longer to obtain a solid wood compression set without the bonding effects of resins. Wang and Cooper (2004) studied the effects of grain orientation and surface plasticizing methods on the vertical density profiles (VDPs) of compressed balsam fir and spruce. In another study, Wang and Cooper (2005) studied the effects of the closing rate of the hot press, the initial moisture content of the wood, and the sample size on the VDPs of thermally compressed fir wood. The density distribution throughout the thickness of wood composites such as fiberboard and oriented strandboard traditionally exhibits higher surface density and lower core density. The density gra- dient is affected by the combined influences of pressure, $\mathrm{MC}$, temperature, resin curing, and other factors during pressing and affects the physical and mechanical properties of wood composites (Wang and Winistorfer, 2000; Candan, 2007; Strickler, 1959; Kamke and Casey, 1988). Since there are differences in material properties and hot pressing parameters for wood composite production, densified solid wood boards could exhibit a different density profile. The Thermal compression process might affect drying characteristics, dimensional stability and density, and hardness and surface quality.

Esteves et al. (2007) utilized a steam heating process on eucalyptus wood and found that the equilibrium MC decreased by $61 \%$ and dimensional stability increased. However, mechanical properties of the material decreased. It was reported that modulus of rupture (MOR) decreased by $50 \%$ and modulus of elasticity (MOE) decreased by $15 \%$. Unsal and Ayrilmis (2005) used a heat treatment process on eucalyptus and determined the properties of density and compression strength. It was stated that density and compression strength decreased with increasing treatment temperature and time. Unsal et al. (2003) studied the effect of the heat treatment process on the physical and mechanical properties of eucalyptus wood. They concluded that density, swelling and Janka hardness values decreased with an increasing duration of heat treatment and temperature.

Unsal and Candan (2008) studied the effectsof press pressure and temperature on vertical density profile, Janka hardness, and MC of pine wood boards. They found that final MC decreased while density and Janka hardness increased. Unsal et al. (2009) used a thermal compression technique on pine wood panels. They used a press temperature of $120^{\circ} \mathrm{C}$ and $150^{\circ} \mathrm{C}$ with a press pressure of 5 and $7 \mathrm{MPa}$. Thickness swelling values for the boards im- 
Oner Unsal, Zeki Candan, Umit Buyuksari, Suleyman Korkut, Yoon-Seong Chang, and Hwanmyeong Yeo

Table 1. Pressing parameters for experimental groups

\begin{tabular}{cccc}
\hline Groups & Pressure (bar) & $\begin{array}{c}\text { Temperature } \\
\left({ }^{\circ} \mathrm{C}\right)\end{array}$ & $\begin{array}{c}\text { Time } \\
(\mathrm{h})\end{array}$ \\
\hline \hline Control & - & - & - \\
A & 40 & 130 & \\
B & 40 & 150 & \\
C & 60 & 130 & 1 \\
D & 60 & 150 & \\
\hline
\end{tabular}

proved except for the boards pressed at $7 \mathrm{MPa}$ at $150^{\circ} \mathrm{C}$.

In this study, the effects of the thermal modification process using a hot-press on final MC, density, VDP, dimensional stability, and Janka hardness of eucalyptus wood boards were investigated.

\section{MATERIALS and METHODS}

\subsection{Material}

In this study, Turkish River Gum (Eucalyptus camaldulensis Dehn.) wood was used. The logs were obtained from the Tarsus region of Mersin, Turkey. Experimental boards with dimensions of $250 \mathrm{~mm}$ by $500 \mathrm{~mm}$ by $16 \mathrm{~mm}$ were cut from the logs. Average initial MC of the samples was $16 \%$.

\subsection{Thermal Compression Process}

The boards were compressed at a press temperature of either $130^{\circ} \mathrm{C}$ or $150^{\circ} \mathrm{C}$ and at a press pressure of either 4 or $6 \mathrm{Mpa}$ for 1 hour in a $500 \mathrm{~mm}$ by $500 \mathrm{~mm}$ laboratory type hot press. A total of five board groups with four treatment groups (A, B, C, and D group) and a control group were investigated. Hot pressing parameters are shown in Table 1.

\section{Thickness Swelling}

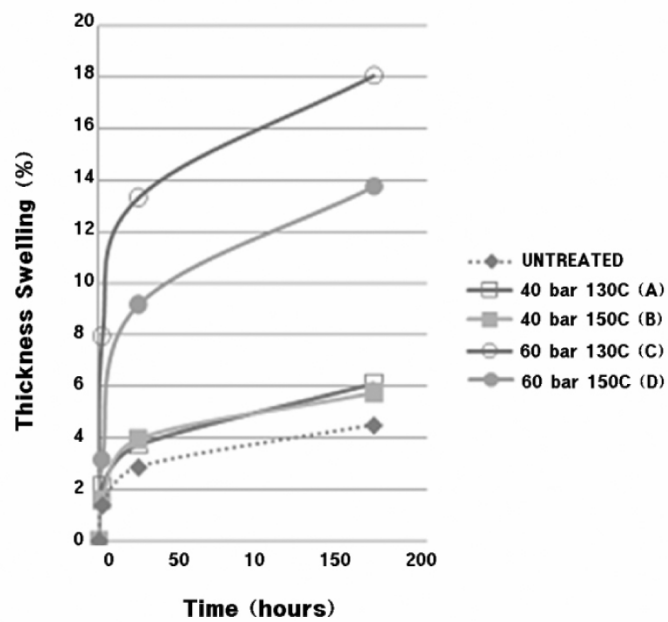

Fig. 1. Thickness swelling (TS) of hot-pressed and untreated specimens after soaking in water.

\subsection{Testing Methods}

Larger specimens with dimensions of $16 \mathrm{~mm}$ (thickness) by $250 \mathrm{~mm}$ (width) by $500 \mathrm{~mm}$ (length) were cut into $16 \mathrm{~mm}$ (thickness) by 50 $\mathrm{mm}$ (width) by $50 \mathrm{~mm}$ (length) for all tests. Radial grain wood specimens were chosen for this study. Since there were two solid wood panels in one treatment group, a total of ten boards were initially used in the five groups and five pressed boards were the end products. Density, vertical density profile, thickness swelling, and Janka hardness were evaluated in this study according to international standards. VDPs weremeasured with an X-ray density profiler (GreCon Measurement Systems, Germany) at Kastamonu Integrated Inc., a quality laboratory located in Kocaeli. The Janka hardness test was done according to ASTM D1037 (1999) standard using a universal test machine. The initial MC of the samples was measured before pressing to determine drying behavior of the panels. After the treatment, the final MC 
Table 2. Thickness swelling of boards

\begin{tabular}{cccc}
\hline \multirow{2}{*}{ Groups } & \multicolumn{3}{c}{ Thickness swelling (\%) } \\
\cline { 2 - 4 } & $2 \mathrm{~h}$ & $24 \mathrm{~h}$ & One week \\
\hline \hline Control & 1.39 & 2.87 & 4.50 \\
$\mathrm{~A}$ & 2.12 & 3.71 & 6.10 \\
$\mathrm{~B}$ & 1.59 & 3.95 & 5.74 \\
$\mathrm{C}$ & 7.95 & 13.33 & 18.07 \\
$\mathrm{D}$ & 3.14 & 9.17 & 13.76 \\
\hline
\end{tabular}

was also measured to evaluate the difference.

\section{RESULTS and DISCUSSION}

\subsection{Thickness Swelling (TS)}

After hot pressing, the thickness of the A, B, $\mathrm{C}$ and $\mathrm{D}$ boards decreased by $27.4 \%, 28.7 \%$, $30.1 \%$ and $31.4 \%$ of original dimension, respectively. Decrement in thickness increased with increasing press time and temperature. $2 \mathrm{~h}$, $24 \mathrm{~h}$ and one week thickness swelling (TS) values of the boards are illustrated in Fig. 1 and shown in Table 2. Among the treated groups, the boards pressed at $4 \mathrm{MPa}$ at $150^{\circ} \mathrm{C}$ (group B) had the lowest thickness swelling value for both $2 \mathrm{~h}$ and one week. The highest thickness swelling values were obtained from boards pressed at $6 \mathrm{MPa}$ at $130^{\circ} \mathrm{C}$ (group C) with $2 \mathrm{~h}$, $24 \mathrm{~h}$, and one week water soaking time.

All thermally pressed panels showed higher thickness swelling values than the control group. This result might be explained by springback due to the boards' densification from the thermal compression process. Thickness swelling values of the treated boards increased with increasing press pressure while the values decreased with increasing press temperature. An Increase in TS values with increasing press pressure could be explained with an increasing springback effect. Improvement in TS with increasing press temperature could be explained

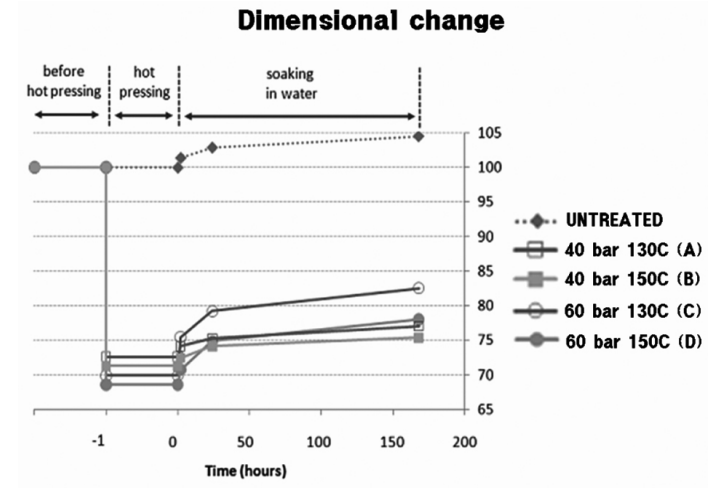

Fig. 2. Thickness of specimen in each state, before hot pressing, after hot pressing and after soaking in water.

by the changes in chemical composition of the wood. In a previous study, Unsal et al. (2009) obtained similar results for pine wood. They reported that thickness swelling and water absorption of thermally hot pressed boards significantly increased with increasing press pressure.

The spring-back phenomenon is greatly controlled by the pressure level, not temperature level. Higher pressure in hot press treatment causes a greater amount of spring-back. On the other hand, higher temperature causes a bigger permanent deformation. Using the above swelling graph and shrinkage data from hot pressing (27.4\% (A), 28.7\% (B), 30.1\% (C), and 31.4\% (D)), a graph can be made to predict the thickness change of the boards quantitatively as shown in Fig. 2. Fig. 2 shows the thickness of the wood in each state : before hot pressing, after hot pressing, and after soaking in water. A specimen's thickness prior to hot-press treatment was assigned as $100 \%$ of the starting dimension thickness. And each dimension of thickness after treatment can be presented by $\%$ scale. Using this \% scale, thickness change of the boards with any other dimension can be predicted.

Fig. 2 shows that a higher pressure applica- 



Fig. 3. Vertical density profile (VDPs) of boards.

tion at the same temperature level and a higher temperature at the same mechanical load (pressure) level in the hot press treatment cause a more decrease in thickness. Viscous and elastic deformation in the thickness decrement can't be separated based on observation of the pressing process. However, the effect of temperature on viscous deformation could be evaluated by comparing the thickness decrement in hot press treatment to the thickness swelling of boards soaked in water. Since a higher temperature application at the same pressure level decreases the amount of spring-back, most of the viscous deformation seems to occur due to the temperature effect.

Moreover, a higher pressure application at the same temperature level increases the amount of spring-back. This means that the pressure induces just recoverable deformation, elastic, and/or viscous-elastic deformation, and there are fewer thermo-chemical modifications in the wood at a higher compressed state. The greater mechanical load by a higher pressure reduces the space in lumen of the woods' cells and the distance between cellulose chains in cell wall structures. The greater mechanical load reduces the space of the lumen and the distance between cellulose chains. It seems that the reduced space in lumen and distance between cellulose chains might interrupt thermo-chemical modifications which cause permanent deformation in wood's cell wall during the hot press treatment.

\subsection{Drying Characteristics}

Average initial MC of the samples was $16 \%$. At the end of the process, similar MC values were obtained. Therefore, it was concluded that the drying effect of hot pressing was not remarkable those conditions. Unsal and Candan (2008) did the thermal compression technique on pine wood panels, and they obtained significant drying effects from the process. One possible reason for the disparity between our study and Unsal and Candan study is that they used a higher press pressure and a higher initial MC. In addition, the wood species used in that study was pine which is softer than eucalyptus wood. 


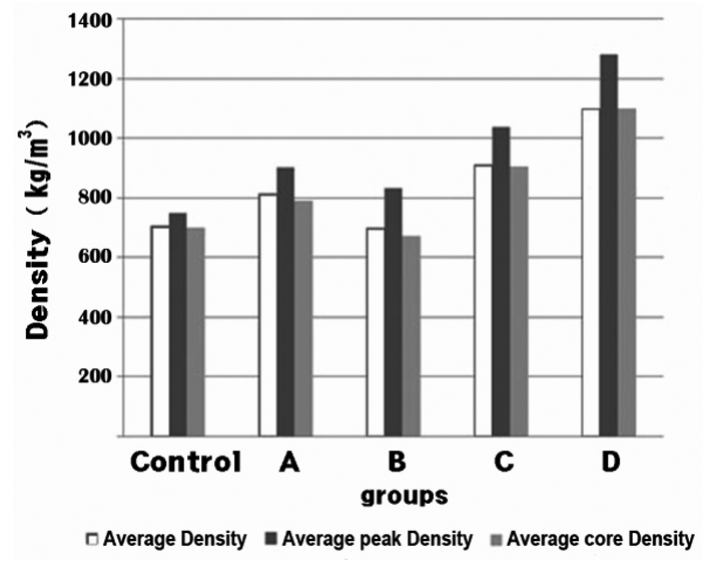

Fig. 4. Density, Peak density (PD) and core density(CD) of thermally modified wood boards.

\subsection{Density and Vertical Density Profile (VDP)}

The VDPs are shown in Fig. 3 and mean density values of the boards are shown in Fig. 4. Group $D$ had the highest mean density value with $1,099 \mathrm{~kg} / \mathrm{m}^{3}$. Group B showed the lowest mean density value with $698 \mathrm{~kg} / \mathrm{m}^{3}$. Mean density values of the boards both pressed at $130^{\circ} \mathrm{C}$ and $150^{\circ} \mathrm{C}$ increased as the press pressure increased. Peak density (PD) and core density(CD) values as VDP characteristics of the boards are shown in Fig. 4. The lowest PD value $\left(748.0 \mathrm{~kg} / \mathrm{m}^{3}\right)$ was observed in the control group while the highest value $\left(1,278.2 \mathrm{~kg} / \mathrm{m}^{3}\right)$ was obtained in group $\mathrm{D}$. The lowest $\mathrm{CD}$ value $\left(668.9 \mathrm{~kg} / \mathrm{m}^{3}\right)$ was observed in group B while the highest value $\left(1,097.5 \mathrm{~kg} / \mathrm{m}^{3}\right)$ was measured in group D. PD values of the boards significantly increased with increasing press pressure for both $130^{\circ} \mathrm{C}$ and $150^{\circ} \mathrm{C}$. PD values of hot pressed boards were higher than the control group. Similarly, Unsal and Candan (2008) found that PD values in the pine wood panels increased with increasing press pressure.
Table 3. Janka hardness of boards

\begin{tabular}{ccc}
\hline Groups & $\begin{array}{c}\text { Janka hardness value Force per unit area } \\
(\mathrm{N})\end{array}$ & 42.95 \\
\hline \hline Control & 4295 & 40.11 \\
A & 4011 & 30.27 \\
B & 3027 & 49.14 \\
C & 4914 & 38.15 \\
D & 3815 & \\
\hline
\end{tabular}

\subsection{Janka Hardness}

Janka hardness was evaluated for the control and all treatment groups as shown in Table 3. The lowest Janka hardness value, 3,027 N, which can be expressed to $30.27 \mathrm{MPa}$ in unit of pressure with consideration of $100 \mathrm{~mm}^{2}$ projected area of steel ball, was observed in group $\mathrm{B}$ while the highest value $(4,914 \mathrm{~N})$ was obtained in group $\mathrm{C}$. When the hot press pressure increased from 4 to $6 \mathrm{MPa}$ at $130^{\circ} \mathrm{C}$, the hardness value increased from 4,011 to $4,914 \mathrm{~N}$. Similarly, when the press pressure increased from 4 to $6 \mathrm{MPa}$, the hardness value of the boards pressed at $150^{\circ} \mathrm{C}$ increased from 3,027 to $3,815 \mathrm{~N}$. The Increase in Janka hardness values can be attributed to an increase in density. The Janka values except for group C were lower than the control group because the brittleness of the boards increased during the hot pressing procedure.

Unsal and Candan (2008) had similar results for the pine boards. It was stated that Janka hardness values increased as press pressure increased. The hardness values were negatively affected by an increase in press temperature. This result was also similar to Unsal et al. (2003). They reported that Janka hardness values of eucalyptus wood significantly decreased with increasing heat treatment temperatures. 


\section{CONCLUSION}

The thermal compression procedure did not improve thickness swelling of the boards. Moisture movement in the wood was not achieved under the treatment conditions because of a low initial MC. Mean density values of the boards increased as press pressure increased. It was concluded that the VDP in the solid wood panels was closely related with the press pressure and pressing temperature. An increase in pressure and temperature resulted in improved $\mathrm{PD}$ and MD values which are defining factors of VDP.

This research showed that the hardness values of Eucalyptus wood boards increased with increasing press pressure for both temperatures. Because of densification on the surface layers of the solid wood boards, hardness values were positively affected. The highest hardness value was obtained in the board pressed at a pressure of $6 \mathrm{MPa}$ at $130^{\circ} \mathrm{C}$.

Consequently, surface hardness of wood materials from fast growing and low quality wood species could be improved by the thermal compression procedure using a hot press. Thus, the use of these wood species might be extended. Future studies will focus on the effects of the pressing parameters on bending properties, surface roughness, and decay and termite resistance of the solid wood boards.

\section{ACKNOWLEDGEMENT}

The authors would like to thank Istanbul University Research Fund (Project Number: "UDP-4766/24122009"). And this study was carried out with the support of 'Forest Science \& Technology Projects (Project No. S120810 L140110)' provided by Korea Forest Service.

\section{REFERENCES}

1. American Society for Testing and Materials ASTM-D 1037. 1999. Standard Test Methods for Evaluating Properties of Wood-Base Fiber and Particle Panel Materials. ASTM International. West Conshohocken, PA.

2. Burmester, A. 1973. Effect of heat-pressure-treatment of semi-dry wood on its dimensional stability. Holz Roh-Werkst 31: 237 243 .

3. Candan, Z. 2007. Effects of some production parameters on vertical density profile (VDP) and technological properties of medium density fiberboard (MDF). MS Thesis, Istanbul University. Istanbul. Turkey. p. 400.

4. Esteves, B., A. V. Marques, I. Domingos, and H. Pereira. 2007. Influence of steam heating on the properties of pine (Pinus pinaster) and eucalypt (Eucalyptus globulus) wood. Wood Science and Technology 41(3): 193 207.

5. Giebeler, E. 1983. Dimensional stabilization of wood by moisture-heat-pressure-treatment. Holz Roh-Werkst 41: 87 94 .

6. Kamke, F. A. and L. J. Casey. 1988. Fundamentals of flakeboard manufacture: Internal mat conditions. Forest Products Journal 38(6): 38 44.

7. Militz, H. 2002. Thermal treatment of wood: European processes and their background. In Proceedings of the 33rd Annual Meeting; CardiffWales. 1217 May, 2002: pp. 1 17. IRG/WP 02-40241.

8. Norimoto, M. 1993. Large compressive deformation in wood. Mokuzai Gakkaishi 39(8): 867 874.

9. Norimoto, M. 1994. Heat treatment and steam treatment of wood. Wood Industry 49(12): 588 592.

10. Seborg, R. M., M. A. Millett, and A. J. Stamm. 1945. Heat stabilized compressed wood (Staypak). Mech. Eng. 67: 25 31.

11. Stamm, A. J. 1964. Wood and cellulose science. Ronald Press. New York. USA.

12. Stamm, A. J. and E. E. Haris. 1953. Chemical processing of wood, Chemical Publishing Co., Inc. New York. USA. 
13. Strickler, M. D. 1959. Effect of press cycle and moisture content on properties of Douglas fir flakeboard. Forest Products Journal 9(7): 203 215.

14. Tarkow, H. and R. M. Seborg. 1968. Surface densification of wood. Forest Products Journal 18(9): $104 \sim 107$.

15. Unsal, O., S. Korkut, and C. Atik. 2003. The effect of heat treatment on some properties and colour in eucalyptus (Eucalyptus camaldulensis Dehn.) wood. MADERAS: Ciencia Y Tecnologia Journal 5(2): 145 152 .

16. Unsal, O. and N. Ayrilmis. 2005. Variations in compression strength and surface roughness of heat-treated Turkish river red gum (Eucalyptus camaldulensis Dehn.) wood. Journal of Wood Science 51: $405 \sim 409$.

17. Unsal, O. and Z. Candan. 2008. Moisture content, vertical density profile and Janka hardness of thermally compressed pine wood panels as a function of press pressure and temperature. Drying Technology 26: 1165 1169.

18. Unsal, O., S. N. Kartal, Z. Candan, R. A. Arango, C. A. Clausen, and F. Green. 2009. Decay and termite resistance, water absorption and swelling of thermally compressed wood panels. International Biodeterioration \& Biodegradation 63(5): 548 552.

19. Wang, J. M., G. J. Zhao, and I. Lida. 2000. Effect of oxidation on heat fixation of compressed wood of China fir. Forestry Studies in China 2(1): 73 79.

20. Wang, J. and P. A. Cooper. 2004. Vertical density profiles in thermally compressed balsam fir wood. Forest Products Journal 55(5): 65 68.

21. Wang, J. and P. A. Cooper. 2005. Effect of grain orientation and surface wetting on vertical density profiles of thermally compressed fir and spruce. Holz als Roh-und Werkstoff 63: 397 402.

22. Wang, S. and P. M. Winistorfer. 2000. Fundamentals of vertical density profile formation in wood composites, Part 2, Methodology of vertical density formation under dynamic condition. Wood and Fiber Science 32(3): 220 238.

23. Yeo, H., J. J. Lee, I. G. Choi, K. J. Yoon, C. D. Eom, J. H. Park, and Y. S. Chang. 2010. Color control of cedar wood and its durability improvement by neat and hot water treatment. In Proceeding of 11th IUFRO Wood Drying Conference. Skelleftea. Sweden. pp. $277 \sim 284$. 